\title{
Safety of repeated cell-free and concentrated ascites reinfusion therapy for malignant ascites from gastrointestinal cancer
}

\author{
OSAMU MAEDA $^{1}$, TAKAFUMI ANDO ${ }^{2}$, KAZUHIRO ISHIGURO $^{2}$, OSAMU WATANABE $^{2}$, \\ RYOJI MIYAHARA ${ }^{2}$, MASANAO NAKAMURA ${ }^{2}$, KOHEI FUNASAKA ${ }^{2}$, \\ FURUKAWA KAZUHIRO ${ }^{2}$, YUICHI ANDO ${ }^{1}$ and HIDEMI GOTO ${ }^{2}$ \\ ${ }^{1}$ Department of Clinical Oncology and Chemotherapy, Nagoya University Hospital; ${ }^{2}$ Department of Gastroenterology \\ and Hepatology, Nagoya University Graduate School of Medicine, Nagoya, Aichi 466-8550, Japan
}

Received May 23, 2014; Accepted July 3, 2014

DOI: $10.3892 / \mathrm{mco} .2014 .335$

\begin{abstract}
Malignant ascites due to peritoneal metastasis is one of the major problems caused by advanced gastrointestinal cancer. Although drainage of a large amount of ascitic fluid improves symptoms such as abdominal fullness, it may lead to protein loss and renal dysfunction. Cell-free and concentrated ascites reinfusion therapy (CART) may help avoid such complications due to paracentesis. The purpose of this study was to evaluate the safety of CART. We performed a total of 51 sessions of CART in 5 patients, 4 of whom had gastric cancer and 1 appendiceal cancer. We retrospectively evaluated laboratory data immediately prior to CART, on the following day, 1 week later and 2 weeks later. We also measured the amount of total protein and albumin in collected and concentrated ascites. The mean amount of collected ascites was 4,007 ml. All the patients exhibited improvement of symptoms such as abdominal fullness. Four patients developed fever $\left(>38^{\circ} \mathrm{C}\right)$ immediately after reinfusion of the concentrated ascites and 3 of these patients required corticosteroid administration. The mean total protein and albumin in the collected ascites were 122 and $64 \mathrm{~g}$, respectively, and those in the concentrated ascites 75 and $39 \mathrm{~g}$, respectively. The serum levels of total protein, albumin and creatinine after CART were almost identical to those prior to CART. Blood hemoglobin concentration was significantly decreased 1 day after CART and returned to baseline levels in 1-2 weeks. CART does not cause renal dysfunction and does not decrease serum albumin; therefore, repeated CART is safe and may be used to improve the symptoms of malignant ascites from gastrointestinal cancer.
\end{abstract}

Correspondence to: Dr Osamu Maeda, Department of Clinical Oncology and Chemotherapy, Nagoya University Hospital, 65 Tsurumai-cho, Nagoya, Aichi 466-8560, Japan

E-mail: maeda-o@med.nagoya-u.ac.jp

Key words: concentrated ascites reinfusion therapy, malignant ascites, gastrointestinal cancer

\section{Introduction}

Malignant ascites is common in gastrointestinal cancer patients with peritoneal metastasis (1). Treatment of malignant ascites includes anticancer drugs, diuretics and paracentesis. Although paracentesis is effective in improving symptoms such as abdominal fullness and appetite loss, it may lead to loss of protein, since malignant ascites contains considerable amounts of protein. Furthermore, the decrease in circulating plasma volume due to drainage of large amounts of ascitic fluid may cause renal dysfunction.

Cell-free and concentrated ascites reinfusion therapy (CART) is reported to be a useful treatment option for improving the symptoms of massive ascites (2-5). CART completely removes cells from the ascitic fluid and returns the protein from the drained ascites into the body of the patient. However, the safety of CART for malignant ascites of gastrointestinal cancer patients has not been fully elucidated.

In the present study, we analyzed laboratory data, including serum albumin and creatinine, prior to and after CART and measured the amount of total protein and albumin in drained and concentrated ascites to evaluate the safety of CART.

\section{Materials and methods}

Patients. A total of 51 sessions of CART were performed in 5 patients (4 with gastric cancer and 1 with appendiceal cancer) at Nagoya University Hospital between September, 2011 and February, 2013. All the patients underwent systemic chemotherapy prior to and after the first session of CART. This study was approved by the Ethics Committee of the Nagoya University Graduate School of Medicine.

CART procedures. We determined the presence of ascites with ultrasonography and puncture was performed with an 18 gauge needle under local anesthesia. Drainage was continued until the flow stopped spontaneously or was interrupted at the physicians' discretion. We confirmed that endotoxins were not detected in the collected ascites, as it is known that CART is unable to eliminate endotoxins with filtration (6). The collected ascites was filtered through the columns of the AHF-MO model (Asahi Kasei Medical, Tokyo, Japan) and 
Table I. Patient characteristics.

\begin{tabular}{|c|c|c|c|c|c|c|c|c|}
\hline $\begin{array}{l}\text { Case } \\
\text { no. }\end{array}$ & $\begin{array}{l}\text { Age, } \\
\text { years }\end{array}$ & Gender & $\begin{array}{l}\text { Origin of } \\
\text { cancer }\end{array}$ & $\begin{array}{c}\text { Pathological } \\
\text { diagnosis }\end{array}$ & Diuretics & $\begin{array}{c}\text { CART } \\
\text { sessions }\end{array}$ & Fever & Corticosteroids \\
\hline 1 & 63 & $\mathrm{~F}$ & Stomach & Tub2-poor & + & 13 & + & - \\
\hline 2 & 69 & $\mathrm{~F}$ & Stomach & Tub2-poor & + & 10 & + & + \\
\hline 3 & 68 & $\mathrm{~F}$ & Stomach & Poor & + & 2 & - & - \\
\hline 4 & 74 & M & Stomach & Poor & + & 8 & + & + \\
\hline 5 & 44 & M & Appendix & Muc & + & 18 & + & + \\
\hline
\end{tabular}

CART, concentrated ascites reinfusion therapy; F, female; M, male; tub2, moderately-differentiated tubular adenocarcinoma; poor, poorly-differentiated adenocarcinoma; muc, mucinous adenocarcinoma.

Table II. Amount of ascites and protein in collected and concentrated ascites in one concentrated ascites reinfusion therapy session.

\begin{tabular}{lr}
\hline Variables & Mean \pm SD \\
\hline Amount of collected ascites $(\mathrm{ml})$ & $4,007 \pm 1,304$ \\
Total protein in collected ascites $(\mathrm{g})$ & $121.6 \pm 47.9$ \\
Albumin in collected ascites $(\mathrm{g})$ & $63.8 \pm 30.7$ \\
Amount of concentrated ascites $(\mathrm{ml})$ & $561.1 \pm 204.9$ \\
Total protein in concentrated ascites $(\mathrm{g})$ & $75.0 \pm 29.8$ \\
Albumin in concentrated ascites $(\mathrm{g})$ & $39.3 \pm 20.8$ \\
Recovery rate of total protein $(\%)$ & $63.1 \pm 14.9$ \\
Recovery rate of albumin $(\%)$ & $63.4 \pm 22.2$ \\
\hline
\end{tabular}

$\mathrm{SD}$, standard deviation.

filtered ascites was then concentrated using the columns of the AHF-UP model (Asahi Kasei Medical). The designed optimal concentration ratio was $1 / 10$. The procedure was continued until the whole amount of ascites was processed or until the filters were clogged.

Statistical analysis. An analysis of variance with repeated measures was used to compare the laboratory data between time points.

\section{Results}

Patient characteristics and CART. We performed a total of 51 sessions of CART in 5 patients. The patient characteristics are summarized in Table I. The interval between CART sessions was $16.5 \pm 12.7$ days (range, 2-66 days; median 14 days). Diuretics were administered to all 5 patients. Four of the 5 patients developed fever $\left(>38^{\circ} \mathrm{C}\right)$ immediately after initiating the reinfusion of concentrated ascites and a corticosteroid was administered to 3 patients as an antipyretic. No other side effects were observed. The amount of collected ascites per session was 1,180-7,210 $\mathrm{ml}$ (mean, 4,007 $\mathrm{ml}$ ). The amount of protein in collected and concentrated ascites is presented in Table II. The recovery rate of total protein and albumin was $\sim 63 \%$. All the patients eventually succumbed to cancer progression.
Comparison of laboratory data. We evaluated laboratory data prior to CART (on the same or previous day), the following day, 1 week (5-10 days) and 2 weeks (11-17 days) later (Table III). Case 2 received albumin transfusion 5 months prior to the first CART session due to hypoalbuminemia and case 5 received an albumin transfusion immediately prior to the last CART to treat septic shock due to pneumonia. We excluded 6 sessions of case 2 from the analysis, as the patient received an erythrocyte transfusion immediately after CART. Out of 51 sessions, 51, 40, 28 and 33 sessions were available for the evaluation of laboratory data prior to CART, on the following day, 1 week later and 2 weeks later, respectively. The serum levels of total protein and albumin after CART were similar to those prior to CART. Hemoglobin and serum creatinine concentration were decreased on the day following CART and recovered to baseline levels in 1 week.

A total of 14 sessions were available for analysis at all 4 time points (Table IV, Fig. 1). Hemoglobin concentration was significantly decreased on the day following CART compared to that prior to CART and recovered to baseline levels in 1 week. There were no significant differences in total protein, albumin and creatinine levels prior to and after CART.

\section{Discussion}

Britton (7) first investigated the use of CART for patients with liver cirrhosis. CART as a treatment for malignant ascites has also been reported for gastrointestinal (3) and gynecological cancers $(3,8,9)$. A comparison between paracentesis with albumin transfusion and CART for liver cirrhosis patients was reported and the two approaches appeared to exert similar effects (10). However, albumin transfusion may cause infection and entails problems associated with the overuse of blood derivatives.

Drainage of massive amounts of ascitic fluid may cause loss of proteins, including albumin, and may lead to renal dysfunction due to the decrease in the circulating fluid volume. We evaluated the changes in laboratory data and found that total protein and albumin after CART remained at similar levels as those prior to CART and that creatinine did not increase after CART. A maximum of 18 sessions of CART were safely performed in 1 patient. The decrease in serum creatinine and hemoglobin on the day following CART is attributed to the dilution due to the increase of circulating blood plasma, as 
Table III. Laboratory data prior to and after concentrated ascites reinfusion therapy (CART).

\begin{tabular}{lcccc}
\hline Variables & Prior to CART & Following day & One week later & Two weeks later \\
\hline Total protein $(\mathrm{g} / \mathrm{dl})$ & $5.65 \pm 0.57$ & $5.50 \pm 0.61$ & $5.79 \pm 0.58$ & $5.68 \pm 0.58$ \\
Albumin $(\mathrm{g} / \mathrm{dl})$ & $2.80 \pm 0.76$ & $2.77 \pm 0.79$ & $2.78 \pm 0.87$ & $2.88 \pm 0.69$ \\
Creatinine $(\mathrm{mg} / \mathrm{dl})$ & $0.81 \pm 0.23$ & $0.67 \pm 0.20$ & $0.86 \pm 0.34$ & $0.78 \pm 0.24$ \\
Hemoglobin $(\mathrm{g} / \mathrm{dl})$ & $10.88 \pm 3.01$ & $9.36 \pm 2.93$ & $10.91 \pm 2.78$ & $10.59 \pm 3.19$
\end{tabular}

Out of 51 sessions, 51, 40, 28 and 33 sessions were available for evaluation of laboratory data prior to CART, on the following day, one week later and two weeks later, respectively.

Table IV. Laboratory data of 14 concentrated ascites reinfusion therapy (CART) sessions for which laboratory data were available at all four time points.

\begin{tabular}{lcccc}
\hline Variables & Prior to CART & Following day & One week later & Two weeks later \\
\hline Total protein $(\mathrm{g} / \mathrm{dl})$ & $5.81 \pm 0.63$ & $5.71 \pm 0.44$ & $5.86 \pm 0.58$ & $5.89 \pm 0.53$ \\
Albumin $(\mathrm{g} / \mathrm{dl})$ & $3.11 \pm 0.72$ & $3.08 \pm 0.72$ & $3.01 \pm 0.75$ & $2.94 \pm 0.81$ \\
Creatinine $(\mathrm{mg} / \mathrm{dl})$ & $0.71 \pm 0.23$ & $0.64 \pm 0.20$ & $0.69 \pm 0.20$ & $0.69 \pm 0.21$ \\
Hemoglobin $(\mathrm{g} / \mathrm{dl})$ & $12.14 \pm 2.53$ & $10.49 \pm 2.51^{\mathrm{a}}$ & $11.95 \pm 2.59$ & $11.81 \pm 3.39$
\end{tabular}

Hemoglobin on the day following CART was significantly lower compared to that prior to CART, one week later and two weeks later $\left({ }^{a} \mathrm{P}<0.01\right)$.

$\mathbf{A}$

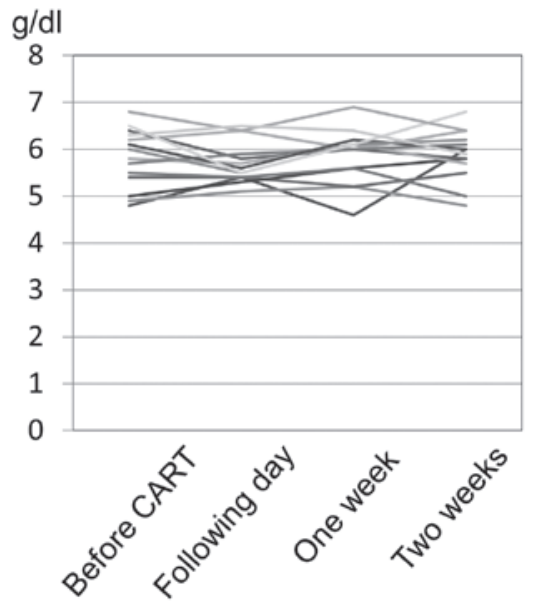

C

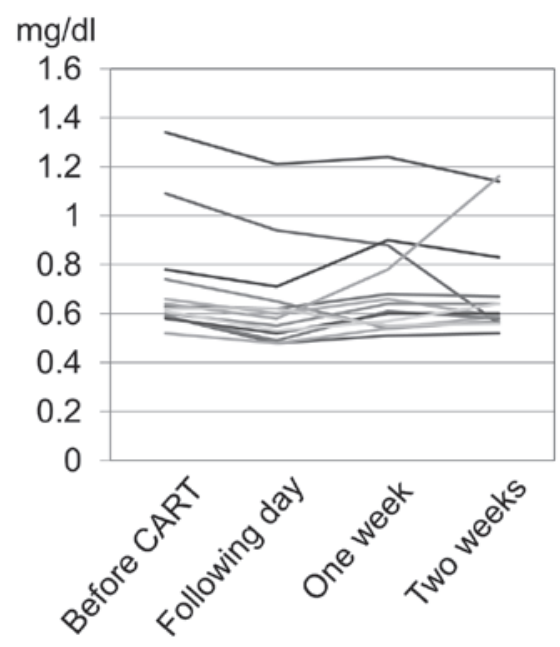

B

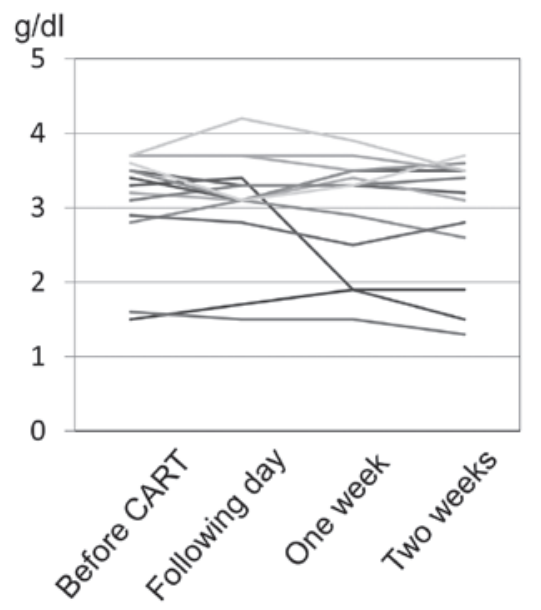

D

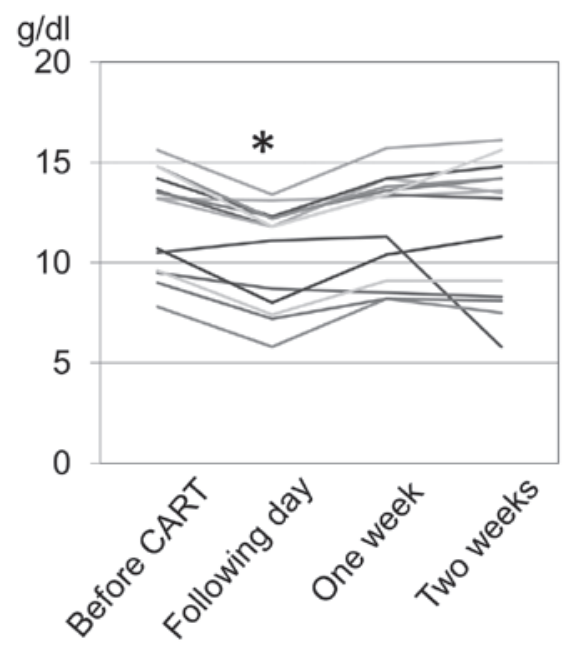

Figure 1. Serum levels of (A) total protein, (B) albumin, (C) creatinine and (D) hemoglobin, measured immediately prior to concentrated ascites reinfusion therapy (CART), on the following day, one week later and two weeks later. Hemoglobin on the day following CART was significantly lower compared to that prior to CART, one week later and two weeks later ( $\mathrm{P}<0.01)$. 
both creatinine and hemoglobin decreased to a similar degree (83 and $86 \%$, respectively) and returned to baseline levels in 1 week. It is considered that this supplementation of plasma volume may contribute to maintaining renal function.

Of the 5 patients, 4 developed fever after CART, which was considered to be caused by substances in ascites. Katoh et al (11) reported that multiple substances, including fibrin, were the cause of fever after the reinfusion of ascites. The inflammatory cytokine interleukin- 6 has also been considered to be a candidate substance causing high fever after CART (12). In our study, corticosteroid was administered at the onset of fever and also administered as a prophylaxis just prior to reinfusion of ascites in patients who had developed fever during prior CART sessions.

In the present study, we analyzed the laboratory data prior to and after CART and concluded that CART was not associated with renal dysfunction and protein loss. Therefore, CART is effective and safe for improving the symptoms of malignant ascites from gastrointestinal cancer.

\section{References}

1. Chung M and Kozuch P: Treatment of malignant ascites. Curr Treat Options Oncol 9: 215-233, 2008.

2. Inoue N, Yamazaki Z, Oda T, Sugiura M and Wada T: Treatment of intractable ascites by continuous reinfusion of the sterilized, cell-free and concentrated ascitic fluid. Trans Am Soc Artif Intern Organs 23: 699-702, 1977.

3. Japanese CART Study Group, Matsusaki K, Ohta K, Yoshizawa A and Gyoda Y: Novel cell-free and concentrated ascites reinfusion therapy (KM-CART) for refractory ascites associated with cancerous peritonitis: its effect and future perspectives. Int J Clin Oncol 16: 395-400, 2011.
4. Nakamoto S, Britton RC and Kolff WJ: Ultrafiltration of ascites. Trans Am Soc Artif Intern Organs 6: 15-21, 1960.

5. Takahashi K, Shibukawa T, Moriyama M and Kitao M: Changes in biochemical data in ascites and serum before and after the treatment of intractable ascites for patients with terminal gynecologic tumor: re-infusion of cell-free and concentrated ascitic fluid. Nihon Gan Chiryo Gakkai Shi 20: 2097-2103, 1985.

6. Maeda A, Takeda K, Tsuruya K, et al: A case of cell-free and concentrated ascites reinfusion therapy effective for refractory ascites in spontaneous bacterial peritonitis in a renal transplant patient. Case Rep Nephrol Urol 2: 138-144, 2012.

7. Britton RC: A new technique for rapid control of cirrhotic ascites. Arch Surg 83: 364-369, 1961.

8. Ueda T, Maehara M, Takahashi Y, et al: Clinical significance of cell-free and concentrated ascites re-infusion therapy for advanced and recurrent gynecological cancer. Anticancer Res 32: 2353-2357, 2012.

9. Kitao M, Takahashi K and Iwaka O: Treatment of intractable ascites at the terminal stage of ovarian carcinoma - reinfusion of the cell-free, concentrated ascitic fluid. Nihon Sanka Fujinka Gakkai Zasshi 35: 1668-1671, 1983 (In Japanese).

10. Graziotto A, Rossaro L, Inturri P and Salvagnini M: Reinfusion of concentrated ascitic fluid versus total paracentesis. A randomized prospective trial. Dig Dis Sci 42: 1708-1714, 1997.

11. Katoh $\mathrm{S}$, Tatsukawa $\mathrm{H}$, Kondoh $\mathrm{M}$, Inoue $\mathrm{M}$, Ida $\mathrm{K}$ and Miyagawa F: Prevention of the febrile reaction occurring on reinfusion of cell-free and concentrated autogenous ascites. Jpn J Med 30: 311-317, 1991

12. Orimi S, Mizuno K, Narahara M, Umakosi H, Kaihara M and Hashimoto M: A study of appropriate flow rate settings for cell-free and concentrated ascites reinfusion therapy and change of cytokine concentrations in ascites. Ther Apher Dial 15: 411-414, 2011. 